\title{
Genetic Variations, Heritability and Genetic Advance Studies among Okra Accessions grown in different Agro-ecological Zones in Nigeria
}

\author{
Agbowuro, G. O. ${ }^{1}$, Salami, A. E. ${ }^{2}$, Awoyemi, S. O. ${ }^{3}$, Ogunwale G. I. ${ }^{4}$, Kehinde-Fadare, A. F. ${ }^{2}$ and Olajide O. O. ${ }^{2}$ \\ ${ }^{1}$ Department of Biological Sciences Elizade University, Ilara Mokin, Ondo State \\ ${ }^{2}$ Department of Crop, Horticulture and Landscape Design, Ekiti state University, Ado-Ekiti \\ ${ }^{3}$ Department of Crop Production Technology, Federal College of Agriculture, Akure \\ ${ }^{4}$ School of Agricultural Technology, Federal University of Technology, Akure
}

\begin{abstract}
How to cite this paper: Agbowuro, G. O., Salami, A. E., Awoyemi, S. O., Ogunwale G. I., Kehinde-Fadare, A. F. and Olajide O. O.. (2019) Genetic Variations, Heritability and Genetic Advance Studies among Okra Accessions grown in different Agro-ecological Zones in Nigeria. International Journal of Food Science and Agriculture, 3(1), 130-135.

DOI: $10.26855 /$ ijfsa.2019.03.001
\end{abstract}

*Corresponding author: Agbowuro, G.O., Department of Biological Sciences Elizade University, Ilara Mokin, Ondo State.

Email: gbenga.agbowuro@elizadeuniversity. edu.ng; Phone: +234 8060260735

\begin{abstract}
Some level of variation within crop varieties is highly important for its improvement with the aids of good plant breeding methods. A field research experiment was carried out with the aim to estimate genetic variation and heritability in the okra accessions grown in different agro-ecological zones in Nigeria. Twenty okra accessions were obtained from various locations in different agro-ecological zones of Nigeria. Twenty okra accessions were evaluated between April to August 2018 at Ekiti State University Teaching and Research Farm, Ekiti State. These twenty okra accessions constituted the treatment, which was lied out in a RCBD in a three replicates. The result were highly significant $(\mathrm{p}<0.01)$ for all the traits studied. Magnitude of the phenotypic coefficient of variances were slightly higher than genotypic coefficient of variances in this study which showed that environment did not much influence the estimates of genetic performance. The coefficient of phenotypic and genotypic variances were high in the traits studied. Heritability estimates ranges from $75.04 \%$ for days to $50 \%$ flowering to $98.85 \%$ for weight of 100 seeds. High heritability with high genetic advance were observed for all the studied traits indicating that they are governed by additive gene action and this could be improved through simple selection except days to $50 \%$ flowering with the lowest heritability value coupled with the lowest genetic advance value lesser than $10 \%$.
\end{abstract}

\section{Keywords}

Heritability, Genetic advance, Improvement, Genetic variability, Okra.

\section{Introduction}

Okra [Abelmoschus esculentus (L) Moench] belongs to family of Malvaceae and genus Abelmoschus [1]. According to [2], okra is proposed to originate from the Tropical Africa from where it extensively spread to Asia, America, Southern Europe and other countries. It is self-pollinated, although 4 to 19 per cent out crossing by insects has been reported which brings about considerable level of genetic [3].Okra fresh fruit contains $175.2 \mathrm{mg}$ minerals, $2.1 \mathrm{~g}$ protein, $0.2 \mathrm{~g}$ fat, $1.7 \mathrm{~g}$ fiber, $8 \mathrm{~g}$ carbohydrate, 36 calories, and $88 \mathrm{ml}$ of water per $100 \mathrm{~g}$ of edible [4].Okra is a high yielding crop under a good cropping system, with yield varying from 4,480 to $5,500 \mathrm{~kg} \mathrm{ha}^{-1}$ of green pods [5].The unripe green finger-like seed capsule of okra, usually called "pod" are processed and consumed as stews and salads, soups, sliced, boiled and fried vegetables [6].

The level of genetic variation present in crop germplasm is proportional to its improvement [7]. Genetic variability cannot be underestimated as a component of plant breeding tool being used to cope with world increasing population on food production [8]. Variation in genetic composition of any given crop population is highly important to successfully select and manage its 
improvement programs [9]. A good understanding of the components of variances and their effects, heritability and genetic advance of the trait(s) of interest help plant breeders in deciding the appropriate breeding method in improving the plant genetic makeup.

To determine the relative environmental influence on expression of genotypes, heritability is highly important. It became very difficult to judge how much of variability is heritable and much of variability is non-heritable. Partition of overall variability into its heritable and non-heritable components with the help of genetic parameters is essentials [10]. who reported that, the higher heritability percentage, the more the heritable variance that may offer the possibility of improvement through selection programme. Estimate of heritability alone is insufficient enough measure of the level of possible genetic progress that might arise in a breeding programme. Genetic advance is also used to enhanced heritability estimates for better improvement in crop [11]. Therefore, this study is to evaluate genetic variation, heritability and genetic advance in various traits in okra accessions grown in some agro-ecological zones in Nigeria, for high yielding okra accession(s) development.

\section{Materials and Methods}

\subsection{Study Area Description}

Field experiment was conducted on okra accessions during the early cropping season in year 2018 in Ekiti State University Teaching and Research Farm, Ekiti State. It lies between latitude $7^{\circ} 31^{\prime}$ and $7^{\circ} 94^{\prime} \mathrm{N}$. The land has been used continuously for the production of crops like yam, melon, cowpea and sweet potato for more than three years.

\subsection{Treatments and Experimental Design}

Twenty okra accessions were obtained from different agro-ecological zones in Nigeria. The twenty accessions used for the experiment and their sources were presented in Table 1. The accessions constituted the treatment, which was lied out in a RCBD in three replicates. Each of the accession were sown in single-row plot to minimise environmental effects associated with large plots. Two seeds were sown per hill by hand and later thinned to one after three weeks of planting. The length of each row was $7.5 \mathrm{~m}$ and plants were sown at the distance of $1 \mathrm{~m}$ x $50 \mathrm{~cm}$. Good crop were raised in the field by adopting excellent agronomic practices. Ten plants were selected randomly for record observations.

\subsection{Data Collection}

Data were collected on final plant height (cm), days to $80 \%$ maturity, fresh fruit length $(\mathrm{cm})$, fresh fruit diameter (cm), days to $50 \%$ flowering, number of fruits per plant, weight of 100 seeds $(\mathrm{g})$, number of seeds per fruit, number of ridges per fruit and fresh fruit yield per plant $(\mathrm{g})$.

\subsection{Statistical Analysis}

\subsubsection{Analysis of variance}

Analysis of variance (ANOVA) was carried out for the traits as per the procedure outlined by [12-13] was used to analyse. The analysis of variance (ANOVA) showing expected means squares is presented in table 2.

\subsubsection{Estimation of genetic parameters}

The components of phenotypic and genotypic variance were calculated according to [14]. Coefficient of variation for phenotypic and genotypic estimate were computed according to by [15] formula. The phenotypic and genotypic coefficient of variation values were categorized by [16] as follows: Low: $0-10 \%$, Moderate: $10-20 \%$, High: $>20 \%$. The Heritability in the broad sense and genetic advance was estimated by adopting [17] method. Genetic advances under selection (GA) expected genetic advances for each trait at five percent selection intensity was calculated by the formula suggested by [17]. The genetic advances as per cent of mean was described by [17] as follows; Low: 0-10 \%, Moderate: 10-20\%, High: $20 \%$ and above.

\section{Results and Discussion}

\subsection{Analysis of variance}

The mean squares due to genotype were highly significantly different $(\mathrm{p}<0.01)$ in all the traits studied. This indicates a wide range of variation and the existence of sufficient genetic variability (Table 2). This is in agreement with the research findings of [18-19].

\subsection{Phenotypic and genotypic variations}

Developing a superior varieties and selecting a good breeding program for any genotype depend on the magnitude of genotypic and phenotypic variability that exist among the genotype. The variability in a given population were measured by genotypic and phenotypic coefficients of variation [14]. In general, whenever phenotypic coefficient value(s) were higher than genotypic coefficient value(s) for any trait, this shows that environmental factors had play a cogent role in influencing the 
trait expression. In this present study, almost similar trend and similar magnitude of phenotypic and genotypic coefficient of variances showed that environment had little influence on the estimates of genetic performance. Highest phenotypic coefficient of variances and genotypic coefficient of variances in all the traits considered were recorded in days to $50 \%$ flowering $(46.09 \%$ and $39.09 \%$ ) respectively. Moreover, high phenotypic and genotypic coefficient of variances were observed in weight of 100 seeds $(36.65 \%$ and $36.39 \%)$ and final plant height (33.75\% and 32.66\%) while fresh fruit length had the least phenotypic and genotypic coefficient of variances $(16.16 \%$ and 14.14 .87$)$ respectively. Final plant height, number of branches per plant, fresh fruit diameter, days to $50 \%$ flowering, days to $80 \%$ maturity, and weight of 100 seeds had phenotypic and genotypic coefficient of variance values greater than $20 \%$ while other studied traits had a phenotypic and genotypic coefficient of variance values greater than $10 \%$ which is moderate. Hence, these traits are responsive to selection for onward improvement. This result substantiates with the findings of [20]. Some researchers have noticed that high magnitude of phenotypic and genotypic coefficient of variance inferred a low environmental manifestation effects on the characters, which probably increase greater improvepment prospects through selection scheme [21-23].

\subsection{Heritability estimates}

Broad sense heritability is an estimate of the total contribution of the genotypic variance to the total phenotypic variance. The relative amount of heritable proportion of variability which is an important biometrical tool for selecting appropriate breeding procedure is determine by heritability. Therefore, it assist the plant breeders to select a particular trait when heritability is high. For this study, heritability in the broad-sense estimates ranged from (75.04\%) for days to 50\% flowering and (98.85\%) for weight of 100 seeds. Agronomic traits seemed to respond effectively to the pressure of selection whenever heritability is up to $60 \%$ or more of a character, selection would be easy for such traits. Broad sense heritability greater than $60 \%$ was obtained for all the traits studied. This result with high broad sense heritability shows that the additive genetic variation was the key component of genetic variation in the inheritance of all these traits. However, improvement can be achieve through direct selection for these traits.

\subsection{Estimates of expected genetic advance}

The genetic advances as percent of the mean (GAM) at 5\% selection intensity is presented in Table 4 . It ranged from $7.11 \%$ for days to $50 \%$ flowering to $74.62 \%$ for plant height at first fruiting.

In all the studied traits, genetic advance expressed as percentage of mean observed was high. From weight of 100 seeds (74.62\%), final plant height $(65.12 \%)$, number of fruit per plant $(48.21 \%)$, fresh fruit diameter $(48.14 \%)$, days to $80 \%$ maturity (45.19\%), number of ridges per plant (39.24), fresh yield per plant (32.80\%), fresh fruit weight per plant (30.94\%) and fresh fruit length $(28.17 \%)$ except days to $50 \%$ flowering $(7.11 \%)$. The high estimate for genetic advance expressed as percentage of mean indicated that these traits were control by additive gene actions which depict that improvement can be made selection for all these traits except days to $50 \%$ flowering $(7.11 \%)$.

Table 1. List of okra accessions and their sources

\begin{tabular}{lll}
\hline ACCESSIONS & Place of Collection & Ecological Zone \\
\hline ACCESSION 1 & Iwo, Osun State & Forest zone \\
ACCESSION 2 & Ado-Ota, Ogun State & Forest zone \\
ACCESSION 3 & Ogbomoso, Oyo State & Forest zone \\
ACCESSION 4 & Ibadan, Oyo State & Forest zone \\
ACCESSION 5 & Odigbo, Ondo State & Forest zone \\
ACCESSION 6 & Orin-Odo-Ekiti, Ekiti State & Forest zone \\
ACCESSION 7 & Oke-Ako- Ekiti, Ekiti State & Forest zone \\
ACCESSION 8 & Irun-Akoko, Ondo State & Forest zone \\
ACCESSION 9 & Uromi, Edo State & Forest zone \\
ACCESSION 10 & Egbe, Kogi State & Derived Savanna \\
ACCESSION 11 & Ilorin, Kwara State & Derived Savanna \\
ACCESSION 12 & Okenne, Kogi State & Derived Savanna \\
ACCESSION 13 & Offa, Kwara State & Derived Savanna \\
ACCESSION 14 & Odo-Owa, kwara State & Derived Savanna \\
ACCESSION 15 & Suleja, Niger State & Southern Guinea Savanna \\
ACCESSION 16 & Mokwa, Niger State & Southern Guinea Savanna \\
ACCESSION 17 & Lafia, Nasarawa State & Southern Guinea Savanna \\
ACCESSION 18 & Kaduna, Kaduna State & Northern Guinea Savanna \\
ACCESSION 19 & Zaria, Kaduna State & Northern Guinea Savanna \\
ACCESSION 20 & Samaru, Kaduna State & Northern Guinea Savanna \\
\hline
\end{tabular}


Table 2. The analysis of variance showing expected means squares

\begin{tabular}{lcl}
\hline S/V & DF & EMS \\
\hline Rep. & $\mathrm{r}-1$ & \\
Accession & $\mathrm{g}-1$ & $\delta^{2} \mathrm{e}+\mathrm{r} \delta^{2} \mathrm{~g}$ \\
Error & $(\mathrm{r}-1)(\mathrm{g}-1)$ & $\delta^{2}$ \\
\hline Where: $\delta^{2} \mathrm{e}:$ Environmental variance, $\delta^{2} \mathrm{~g}:$ Genotypic variance, $\mathrm{S} / \mathrm{V}:$ Source of variation \\
DF: Degree of Freedom, EMS: Expected Means Squares
\end{tabular}

\section{Conclusion}

The result showed the existence of genetic variability in the okra accessions studied and this can be exploited in the future breeding program. The mean squares due to genotype were highly significantly different $(p<0.01)$ for all the studied traits, almost similar trend and similar magnitude of phenotypic and genotypic coefficient of variances were also observed in the result. Heritability in the broad-sense values were higher than $60 \%$ in all the studied traits, likewise the estimate for genetic advance expressed as percentage of mean indicated that these traits were greater than $20 \%$ except days to $50 \%$ flowering. Considering the result in this study, there is an indication of preponderance of additive gene actions and improvement can be made through selection except days to $50 \%$ flowering.

Table 3. Combined ANOVA for 10 okra traits studied, the values are mean square.

\begin{tabular}{llllllllllll}
\hline S. of V & DF & FPH (cm) & D80\%M & FFL (cm) & FFD (cm) & D50\%TF & NOF/P & W100S (g) & NOS/F & NOR/F & FFY/P(g) \\
\hline Rep. & 2 & $102.73^{*}$ & $22.68^{* *}$ & $13.75^{* *}$ & $12.58^{* *}$ & $124.17^{* *}$ & $60.07^{* *}$ & $11.45^{*}$ & $84.63^{* *}$ & $11.46^{* *}$ & $0.22^{*}$ \\
Acc. & 19 & $2139.09^{* *}$ & $6.41^{* *}$ & $3.71^{* *}$ & $15.55^{* *}$ & $12.94 * *$ & $115.56^{* *}$ & $1672.21 * *$ & $134.79 * *$ & $7.27 * *$ & $1.07 * *$ \\
Error & 38 & 0.12 & 0.21 & 1.47 & $1 . .47$ & 1.29 & 1.49 & 7.95 & 4.64 & 0.12 & 0.03 \\
\hline
\end{tabular}

$*$, ** significant at $5 \%$ and $1 \%$ levels respectively

Rep.: replication, Acc.: Accession, FPH: final plant height, D80\%M: days to 80\% maturity, FFL: Fresh fruit length FFD: Fresh fruit diameter, D50\%TF: 50\% days to fruiting, NOF/P: Number of fruits per plant,

W100S (g): weight of 100 seeds (g), NOS/F: Number of seeds per fruit, NOR/F: Number of ridges per fruit, FFY/P: fresh fruit yield per plant $(\mathrm{g})$.

Table 4. Mean, Standard Error, Range, Phenotypic and Genotypic Variances

\begin{tabular}{llllc}
\hline Character & Means \pm S.E & Range Min-Max & Genotypic variances & Phenotypic variances \\
\hline FPH (cm) & $80.83 \pm 3.97$ & $38.60-125.60$ & 697.30 & 744.49 \\
D80\%M & $6.24 \pm 0.19$ & $2.50-10.50$ & 2.0 & 2.12 \\
FFL (cm) & $7.24 \pm 0.26$ & $4.80-7.24$ & 1.16 & 1.37 \\
FFD (cm) & $8.08 \pm 0.70$ & $3.80-19.2$ & 4.69 & 6.16 \\
DTF & $49.33 \pm 0.65$ & $44.0-57.4$ & 3.88 & 5.17 \\
NOF/P & $25.82 \pm 0.7$ & $17.4-38.80$ & 38.02 & 39.51 \\
W100S (g) & $64.72 \pm 1.63$ & $26.2-100.1$ & 554.75 & 562.70 \\
NOS/F & $41.72 \pm 1.24$ & $20.4-53.20$ & 43.38 & 48.02 \\
NOR/F & $7.90 \pm 0.20$ & $6.00-12.00$ & 2.38 & 2.50 \\
FFY/P(g) & $3.14 \pm 0.10$ & $2.00-4.10$ & 0.34 & 0.37 \\
\hline
\end{tabular}

FPH: final plant height, D80\%M: days to $80 \%$ maturity, FFL: Fresh fruit length

FFD: Fresh fruit diameter, D50\%TF: 50\% days to fruiting, NOF/P: Number of fruits per plant,

W100S (g): weight of 100 seeds (g), NOS/F: Number of seeds per fruit, NOR/F: Number of ridges per fruit, FFY/P: fresh fruit yield per plant $(\mathrm{g})$. 
Table 5: Phenotypic and Genotypic Coefficients of Variation, Heritability and Genetic Advance

\begin{tabular}{|c|c|c|c|c|c|}
\hline Character & $\begin{array}{c}\text { Heritability } \\
\text { (Broad sense) \% }\end{array}$ & $\begin{array}{c}\text { Genotypic Coefficients } \\
\text { of Variation }(\%)\end{array}$ & $\begin{array}{c}\text { Phenotypic Coefficients } \\
\text { of Variation }(\%)\end{array}$ & $\begin{array}{c}\text { Genetic dvance } \\
(\%)\end{array}$ & $\begin{array}{c}\text { G.Amean } \\
(\%)\end{array}$ \\
\hline FPH $(\mathrm{cm})$ & 93.66 & 32.66 & 33.75 & 52.64 & 65.12 \\
\hline D80\%M & 94.33 & 22.6 & 23.33 & 2.82 & 45.19 \\
\hline FFL (cm) & 84.67 & 14.87 & 16.16 & 2.04 & 28.17 \\
\hline FFD (cm) & 76.13 & 26.80 & 30.71 & 3.89 & 48.14 \\
\hline $50 \%$ DTF & 75.04 & 39.93 & 46.09 & 3.51 & 7.11 \\
\hline NOF/P & 96.22 & 23.88 & 24.34 & 12.45 & 48.21 \\
\hline W100S(g) & 98.85 & 36.39 & 36.65 & 48.30 & 74.62 \\
\hline NOS/F & 90.33 & 15.78 & 16.60 & 12.91 & 30.94 \\
\hline NOR/F & 95.20 & 19.52 & 20.01 & 3.10 & 39.24 \\
\hline FFY/P(g) & 91.89 & 18.56 & 19.37 & 1.03 & 32.80 \\
\hline
\end{tabular}

FPH: final plant height, D80\%M: days to $80 \%$ maturity, FFL: Fresh fruit length

FFD: Fresh fruit diameter, D50\%TF: 50\% days to fruiting, NOF/P: Number of fruits per plant,

W100S (g): weight of 100 seeds (g), NOS/F: Number of seeds per fruit, NOR/F: Number of ridges per fruit, FFY/P: fresh fruit yield per plant $(\mathrm{g})$.

\section{References}

[1] Schippers R.R, (2000). African indigenous vegetables. In: An overview of the cultivated species. Natural Resources Institute/ACP-EU Technical Center for Agricultural and Rural Cooperation, Chatham, UK. pp: 103-118.

[2] Muhammad, R. S., Muhammad A., Khurram, Z., Muhammad, M. J., Saeed, A., Qumer, I. and Aamir, N. (2013). Growth, yield and seed production of okra as influenced by different growth regulators. Pakistan Journal of Agricultural Science, 50(3), 387-392.

[3] Choudhury B. and Choonsai, M.L.A. (1970). Natural cross-pollination in some vegetable crops. Indian J. Agric Sci. 1970; 40(9): 805-812.

[4] Tindall H.D. (1983). Vegetables in the tropics. Macmillan Press Ltd., London and Basingstoke. pp: 25-328

[5] Ayodele O.J. (1993). Yield responses of okra [A. esculentus (L.) Moench] to fertilizer. NIHORT Research Bulletin, 13 pp

[6] Akanbi, W.B., Togun, A. O., Adediran J. A. and Ilupeju, E. A. O. (2010). Growth, dry matter and fruit yield components of okra under organic and inorganic sources of nutrients. American-Eurasian Journal of Sustainainable Agriculture, 4(1), $1-13$.

[7] Aladele, S. E. (2009). Morphological distinctiveness and metroglyph analysis of fifty accessions of west African Okra. J. Pl. Breed. Crop Sci. 1: 273-80

[8] Ariyo, O.J. (1990). Variation and heritability of fifteen characters in okra (Abelmoschus esculentus (L) Moench) Trop. Agric. 67: 3, 213 - 216.

[9] Ndukauba, J., Nwofia, G.E., Okocha, P.I and Ene-Obong, E.E. (2015). Variability in Egusi-Melon Genotypes (Citrullus lanatus [Thumb] Matsum and Nakai) in derived Savannah environment in South-Eastern Nigeria. International Journal of Plant Research 5(1):19-26. doi:10.5923/j.plant.20150501.04.

[10] Ansari, B. A., Ansari, K. A.and Khund, A. (2004). Extent of heterosis and heritability in some quantitative characters of bread wheat. Indus. J. Pl. Sci., 3, 189-192.

[11] Ibrahim M.M. and Hussein, R.M. (2006). Variability, heritability and genetic advance in some genotypes of roselle (Hibiscus sabdariffa L.). World J Agr Sci 2(3): 340-345.

[12] Gomez, A. K. and Gomez, A. A. (1984). Statistical procedures for Agricultural Research, 2nd edition. John and Sons, inc., Institute of Science pub. New York.679pp 
[13] SAS Institute, 2002. SAS /STAT Guide for personal computers, version 9.0 editions. SAS Institute Inc., Cary, NC, USA.

[14] Burton, G.W. and De Vane, E.H. (1953). Estimating heritability in tall fescue from replicated clonal material. Agronomy Journal 45: 478-481.

[15] Burton, G.W. (1952). Quantitative inheritance of grasses. Proc. 6th int. Grass. Cong 1: 277-283.

[16] Sivasubramaniah, S. and Menon, M., (1973). Heterosis and inbreeding depression in rice. Madras Agric. J., 60 : 1139.

[17] Johnson, H. W., Robinson, H. F. and Comstock, R. E. (1955). Estimation of genetic and environmental variability in soybeans. Agronomy Journal, 47, 314-318. doi:10.2134/agronj1955.00021962004700070009x

[18] AdeOluwa, O. O., Kehinde, O. B. (2011). Genetic variability studies in West African Okra (Abelmoschus caillei). Agriculture and Biological Journal of North America, 2(10): 1326-1335. doi:10.5251/abjna.2011.2.10.1326-1335.

[19] Muluken, D., Wassu, M. and Endale G.(2016). Variability, heritability and genetic advance in Ethiopian okra [Abelmoschus esculentus (L.) Monech] collections for tender fruit yield and other agro-morphological traits. Journal of Applied Life Sciences International, 4(1), 1-12. doi:10.9734/JALSI/2016/19483

[20] Ehab, A. A. I., Mohamed, Y. A. and Ali, M. M. (2013). Genetic behavior of families selected from some local okra [Abelmoschus esculentus (L.) Moench] populations in Egypt. Plant Breeding and Biotechnology, 1(4), 396 -405. doi:10.9787/PBB.2013.1.4.396

[21] Salesh K. J., Deepak, A. and Ghai, T. R. (2010). Variability studies for yield and its contributing traits in okra. Electronic Journal of Plant Breeding, 1(6), 1495-1499.

[22] Swati, B., Reena,N., Meenakshi, R. and Jain, P. K (2014). Genetic variability in okra [Abelmoschus esculentus (L.). Moench]. An International Quarterly Journal of Environmental Sciences, 6, 153-56.

[23] Kishor, D. S., K. Arya, K. J. Yogeesh, K. Y. Vinod, K. Hee-Jong, 2016. Genotypic variation among okra (Abelmoschus esculentus (L.) Moench) germplasms in South Indian Plant Breeding and Biotechnology, 4(2), 234-241. doi:10.9787/ PBB.2016.4.2.234 